\title{
Dois precisos poemas de futebol
}

\section{Renato Negrão}

A revista FuLiA/UFMG apresenta um par de poema futebolístico, "Dadá" e "Futebol para todos", de Renato Negrão. 0 primeiro foi publicado na abertura de seu livro Vicente viciado (Rótula, 2012) e o outro na antologia Pe-

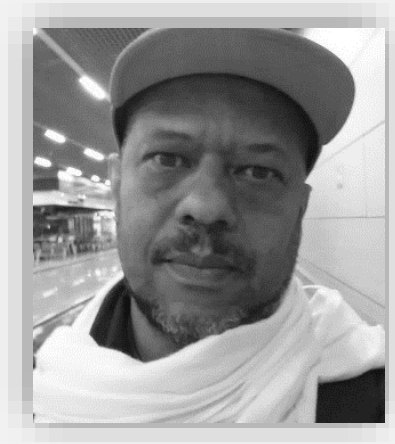
lada poética - Copa do Mundo no

Brasil (Scriptum, 2014), organizada por Welbert Belfort e Mário Alex Rosa.

Esses poemas vistos pelo prisma da temática do dossiê, o estudo do esporte por meio de metodologias quantitativas, nos fazem refletir se os números contariam tudo que almejamos saber. Afinal, desdobra a facilidade com que o ex-jogador Dadá concretizava a bola no fundo da rede. Para isso, Negrão destaca tanto o uso da matematicidade da "raiz quadrada", quanto a aplicação da sutileza mirabolante do atacante. Já o poema "Futebol para todos" nos permite refletir sobre as formas de investigar os nossos objetos de pesquisa. 0 poeta mostra como precisamos questionar para saber sobre eles e, ainda mais importante, uma análise das respostas "(re)colhidas" nos permite compreender a essência do objeto.

Renato Negrão nasceu em Belo Horizonte, capital de Minas Gerais, em 1968. É poeta, artista visual e educador - Prêmio Itaú Rumos Educação, Cultura e Arte 2008/2010. Dentre outras publicações de sua autoria, destacam-se Odisseia vácuo (2017), Os dois primeiros e um lote vago (2004), Dragões do paraíso (1997), com Daniel Costa, na coleção Poesia Orbital, organizada por Marcelo Dolabela, e No calo (1996).

Possui gravações e parcerias musicais com Makely Ka, Juliana Perdigão, Kristoff Silva, Sérgio Pererê, Estrela Leminski, Alice Ruiz e Angélica Freitas. Site: https://www.renatonegrao.org. 


\section{Futebol para todos}

\section{\# Proposição - da estética}

ligar para a associação nacional dos árbitros de futebol e perguntar a funcionários de cargos distintos de que serve a meia-lua anote as respostas \& caso não se convença - o que provavelmente ocorrerá dirija-se à porta da instituição e grite

de que serve a meia-lua

grite

de que raios serve a meia-lua até que seu corpo adquira a curvatura de um lobo ganindo ao limite de ainda observar como e quantos se compadecem do seu drama a meia-lua

esse mero formalismo estético

\# Jogo - da produção de fenômenos de linguagem

às pessoas

mais ou menos

desinteressadas

em futebol

indague-as para que

lhe expliquem

a lei

do impedimento

\& das

$$
\text { respostas }
$$

(re)colhidas

poderá você

obter largo material

$$
\text { e sutis }
$$

articulações linguísticas

$$
\text { em poética }
$$

de alta voltagem

\# Apontamento - da fonética

o juiz diz

que não

(h)ouve

nada 


\section{Dadá}

- futebol é o seguinte

chegou ali e tem tranquilidade

é só aplicar o sutil o mirabolante

a raiz quadrada o labirinto

que não tem jeito pro goleiro não

é cair e levantar para buscar

o caroço lá dentro

- que negócio é esse de sutil mirabolante e raiz quadrada

— não posso dizer

é segredo profissional

outro dia criei mais um gol

o independência

— poesia é o seguinte

chegou ali e tem tranquilidade

é só aplicar o sutil o mirabolante

a raiz quadrada o labirinto

que não tem jeito pro leitor não

é cair e levantar para buscar

o caroço lá dentro

- que negócio é esse de sutil mirabolante e raiz quadrada

— não posso dizer

é segredo profissional

outro dia criei mais um poema

o independência

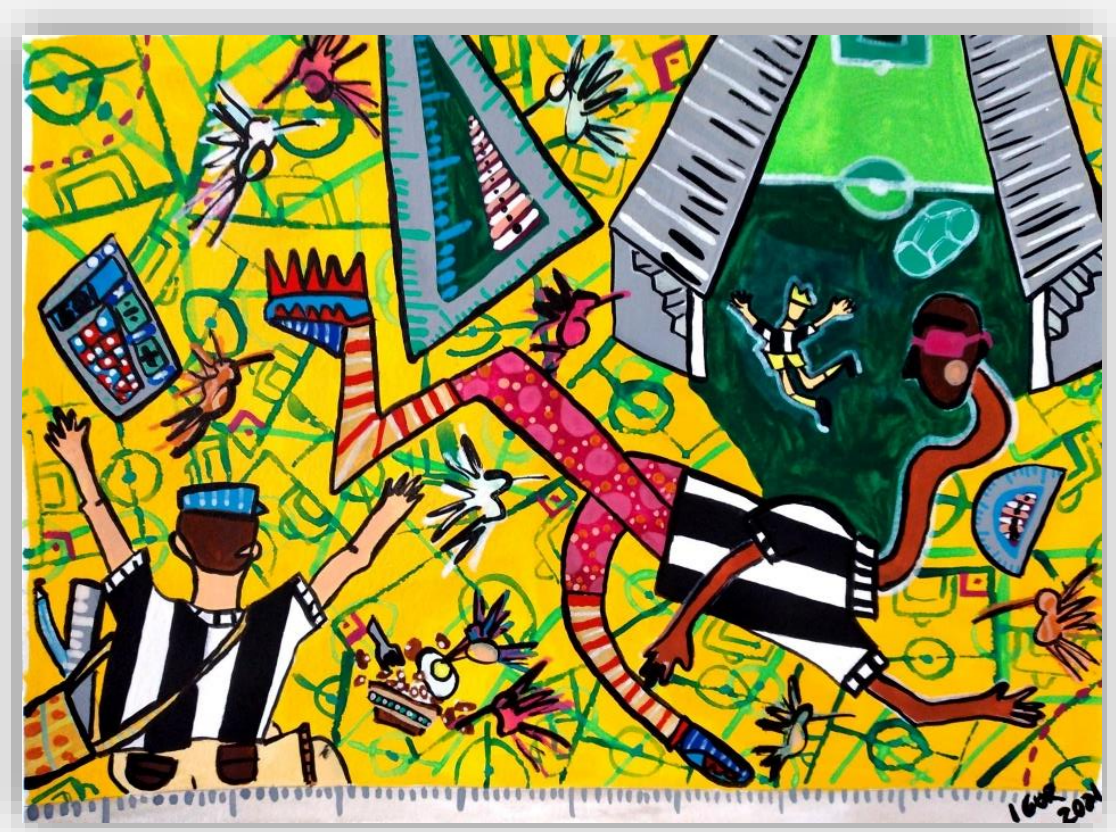

Desenho - Igor Maciel da Silva, nanquim e aquarela s/ canson
$@$ coresdeigor

Capa da revista FuLiA/UFMG, v. 6, n. 1, 2021 O esporte pelo prisma dos métodos quantitativos. 


\section{Toca Dadá}

O poema "Dadá", em homenagem ao lendário atacante do Atlético Mineiro, Dario José dos Santos - o "Dadá Maravilha" ou "Dadá Beija-flor" ou ainda "Peito de Aço" -, nascido no Rio de Janeiro, em 1946, mas radicado em Belo Horizonte, foi gravado por Renato Negrão, sonorizado por Fabiano Fonseca e, desde 2014, integrado à instalação poética no Museu Brasileiro do Futebol (Estádio Mineirão), concebida pelo pesquisador Gustavo Cerqueira. Esse poema também foi publicado pela revista Em Tese, ao lado de outros três do autor, na série intitulada "Desenrolando Barthes e outras semiologias" (2015).

Em nota preciosa do livro Vicente viciado (2012), Negrão nos informa que concebeu o poema "Dadá" a partir de uma entrevista dada pelo jogador ao jornal 0 Pasquim, em 1972, pouco tempo depois do ídolo atleticano ter se sagrado campeão e artilheiro do Campeonato Brasileiro pelo Atlético, há 50 anos.

Além de ser um dos principais centroavantes do futebol brasileiro dos anos 1970, Dadá, tricampeão da Copa do Mundo no
México, na suplência, foi um extraordinário comunicador, capaz de mobilizar a atenção da mídia especializada por meio de seu carisma e de emblemáticos bordões: "Somente três coisas param no ar: o beija-flor, o helicóptero e Dadá”, em alusão a sua habilidade de cabecear a bola, o que lhe confere o título de artilheiro mundial nesse quesito; "Não existe gol feio, feio é não fazer gol”; e "Não me venham com a problemática que eu tenho a solucionática", mencionada por ninguém menos que o poeta Carlos Drummond de Andrade no Jornal do Brasil, em 1971.

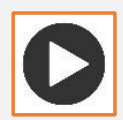

Para ouvir o poema acesse o link: https://bit.ly/FuLiA/UFMG-Negrao-Dada. 